\title{
Role of nesfatin-1 in the metabolism of skeletal tissues
}

\author{
IWONA PUZIO, GRZEGORZ TYMICKI, HANNA PREDKA, WIESŁAW ŚLEBODA, \\ MAGDALENA SOBCZYŃSKA-WOKEJSZO
}

\begin{abstract}
Department of Animal Physiology, Faculty of Veterinary Medicine, University of Life Sciences in Lublin, Akademicka 12, 20-033 Lublin
\end{abstract}

\section{Puzio I., Tymicki G., Predka H., Śleboda W., Sobczyńska-Wołejszo M. Role of nesfatin-1 in the metabolism of skeletal tissues \\ Summary}

NUCB2/nesfatin-1, a member of the adipokine family, is a peptide hormone with pleiotropic action. It has been found in different tissues, including cartilage and bone cells. Nesfatin-1 is produced by chondrocytes, and its synthesis increases with the degree of cell differentiation and upon stimulation by pro-inflammatory cytokines, as shown in an in vitro study. An increase in serum levels of nesfatin-1 has been observed in humans with osteoarthritis, which indicates the influence of pro-inflammatory cytokines on nesfatin-1 release. On the other hand, nesfatin-1 stimulates the synthesis of pro-inflammatory cytokines by chondrocytes, which suggests its participation, together with other adipokines, in the pathogenesis and/or progression of inflammatory complications of cartilage degenerative diseases. Nesfatin- 1 also promotes pre-osteoblastic cell differentiation and mineralization and inhibits macrophage differentiation towards osteoclasts. Moreover, exogenous nesfatin-1 given to ovariectomized rats reduces osteopenic changes. Therefore, it seems that nesfatin- 1 may play a protective role in cartilage and bone diseases. However, further studies are required to determine whether nesfatin-1 can be used for monitoring and treatment of cartilage and bone diseases.

Keywords: nesfatin-1, NUCB2, bone, cartilage, skeletal tissue

Skeletal disorders are a serious problem in humans and animals. Since they are multifactorial diseases, their treatment is relatively difficult. Therefore, the exact knowledge of mechanisms regulating bone metabolism is important for choosing appropriate preventive procedures. Due to the severity of the problem, in recent years attention has been paid to the role of various factors in the physiology of bone and cartilage tissues. The current data indicate that some adipokines, e.g. adiponectin, visfatin, resistin, and the best-known leptin, exert a complicated and inconsistent effect on bone metabolism $(4,5,8,13,28,33,40,45,57,66)$. These findings are the basis for the claim that nesfatin- 1 as an adipokine may play an important role in the metabolism of skeletal tissue as well.

Nesfatin-1, i.e. an 82-amino-acid peptide, was first described by Oh-I and co-workers in 2006 (38). It was found as an anorexigenic protein derived from nucleobindin-2 (NUCB2) and was named NUCB2encoded satiety and fat-influencing protein/nesfatin-1. Therefore, nesfatin-1 is frequently called NUCB2.

Nucleobindin was identified in the 1990s as a protein capable of binding $\mathrm{Ca}^{2+}$ ions, located in the nucleus, the Golgi apparatus, and the endoplasmic reticulum $(3,35)$. Further investigations revealed two types of this protein: nucleobindin-1 (NUCB1) and nucleobindin-2 (NUCB2). NUCB2 has a 24-amino acid signal peptide at the $\mathrm{N}$-terminus and a chain consisting of 396 amino acids characterized by a constant sequence in rodents and humans. As a result of post-translational changes in the NUCB2 molecule in the presence of prohormone convertase (PC) $-1 / 3$, three peptides are distinguished: nesfatin-1 (residues 1-82), nesfatin-2 (residues 85-163), and nesfatin-3 (residues 166-396) (47). It has been found in studies on these peptides that only nesfatin- 1 shows biological activity, and its effect is based on the inhibition of food intake in rats after either peripheral or central administration (14, $17,21,38,47,49,50)$.

\section{Location of nesfatin-1 in the body}

Initially, NUCB2/nesfatin-1 mRNA expression was found in neurons of the hypothalamus and brainstem, such as the paraventricular nucleus, supraoptic nucleus, arcuate nucleus, lateral hypothalamus, zona incerta, and solitary tract nucleus. Immunohistochemical stud- 
ies showed the same location of nesfatin-1 $(6,38)$. In fact, NUCB2/nesfatin-1 is abundantly expressed in several regions of the hypothalamus that play key roles in controlling food intake. It is now known that immunopositive reaction to NUCB2/nesfatin-1 also occurs in other areas, including the periventricular nucleus, Edinger-Westphal nucleus, dorsal nucleus of the vagus nerve, insular cortex, cerebellum as well as sympathetic and parasympathetic neurons of the spinal cord within the thoracic, lumbar, and sacral parts (6, $14,16,20,24,31,38,62)$. Within neurons, nesfatin-1 occurs in conjunction with different neurotransmitters, including primarily melanin (MEL), cocaine- and amphetamine-regulated transcript (CART), proopiomelanocortin (POMC), $\alpha$-melanocyte-stimulating hormone $(\alpha-\mathrm{MSH})$, growth hormone-releasing hormone (GHRH), thyrotropin-releasing hormone (TRH), corticotropin-releasing hormone $(\mathrm{CRH})$, oxytocin (OT), vasopressin (AVP), neurotensin (NT), acetylocholine (Ach), and serotonin (SER) (6, 12, 14, 16, 31, $34,39)$. The anatomical location of neurons expressing nesfatin- 1 and its coexistence with neurotransmitters suggests that the physiological role of nesfatin- 1 is not limited to the regulation of food intake, but also includes the regulation of neuroendocrine and autonomic control of internal organs and emotional reactions $(14,22,34)$.

The expression of NUCB2/nesfatin- 1 mRNA was also observed in peripheral tissues, including the stomach, duodenum, pancreas, heart, adipose tissue, and testis $(19,23,44,48,65)$. Gastric NUCB2/ nesfatin-1 mRNA expression levels were higher than expression levels in other peripheral organs and brain (48). Nesfatin-1 reduced the release of gastric acid in a dose-dependent manner and influenced gastrointestinal motility $(2,24,55,58)$. Its presence in pancreatic cells was detected particularly in the beta cells of Langerhans islets $(15,27)$. Nesfatin-1 stimulates the release of insulin in response to glucose and increases mRNA expression of preproinsulin in isolated islets of Langerhans in rats and mice via an intracellular signal associated with the influx of $\mathrm{Ca}^{2+}$ through longterm L-type calcium channels $(26,36)$. Intravenous nesfatin-1 injections lower plasma glucose in obese mice with phenotype $\mathrm{db} / \mathrm{db}$ as well as in non-diabetic and non-obese mice (51). Moreover, elevated glucose in blood increases the release of nesfatin-1 from endocrine cells of the pancreas (11), suggesting that nesfatin-1 may affect the control of blood glucose by insulin. However, as shown by some researchers, nesfatin-1 serves only a local function in the pancreas (7).

Nesfatin-1 also exerts other effects on the organism. This peptide influences water intake (64), energy expenditure (56), sleep (54), blood pressure $(61,63)$, and reproduction $(18,19)$. Serum nesfatin-1 levels correlated positively with increasing BMI, demonstrating that systemic nesfatin-1 levels may be influenced by the body fat $(1,44)$. Human and murine adipocytes are capable of producing nesfatin-1, which confirms that this anorexigenic molecule is an adipokine. Hence, a potential source of peripheral nesfatin-1 is white adipose tissue, especially the subcutaneous tissue (44).

\section{Location and function of nesfatin-1 in bone and cartilage}

The first studies concerning the interaction of nucleobindin and bone indicated that this protein was a product of bone cells, osteoblasts and osteocytes, and that it was secreted into the osteoid (42). Its intracellular and extracellular location was found. However, immunohistochemistry analysis detected the most intense nucleobindin labeling extracellularly in newly formed bone in growing rats, whereas in compact bone, labeling for nucleobindin was located in osteocytes. The expression of nucleobindin was up-regulated during differentiation and matrix maturation, and subsequently down-regulated during mineralization (42). These observations suggest that nucleobindin might play a role as a modulator of matrix maturation and might be important for transcellular $\mathrm{Ca}^{2+}$ transport during mineralization. The studies mentioned above were the basis for further research. However, at present, research on the role of nesfatin- 1 in bone and cartilage physiology is very limited. Preliminary papers in this field date from 2013 and later.

Jiang et al. (30) demonstrated nesfatin-1 gene expression in articular cartilage, osteophytes, meniscus, synovium, and intrapatellar fat pads in samples of osteoarthritis cartilage and non-osteoarthritis cartilage. The higher mRNA nesfatin-1 expression in osteoarthritis cartilage indicates that nesfatin-1 may be involved in the pathogenesis of osteoarthritis. Immunohistochemical analysis indicated that all osteoarthritis cartilage, osteophyte, and synovium contained nesfatin-1. In the synovium and osteophytes, nesfatin-1 was present notably in the superficial layers. Nesfatin-1 staining was stronger in lesional areas of cartilage than in non-lesional areas. Significantly elevated levels of nesfatin-1 in patients with osteoarthritis, compared with serum from healthy controls, were also confirmed $(30,67)$. Furthermore, correlations were observed between serum nesfatin- 1 and high sensitivity C-reactive protein (hsCRP) levels and between synovial nesfatin-1 and IL-18 (interleukin-18) levels in osteoarthritis patients. IL-18 and hsCRP are associated with cartilage inflammation $(29,41)$. Thus, the relationship of IL-18, hsCRP, and nesfatin-1 may indicate that nesfatin-1 could be a novel marker of osteoarthritis. Moreover, as reported by Zhang et al. (67), serum and synovial fluid nesfatin-1 concentrations were associated with osteoarthritis development. On the other hand, the fact that the nesfatin-1 level in serum, observed by Jiang et al. (30), was significantly higher than it was in synovial fluid indicates that circulating levels of nesfa- 
tin-1 do not accurately represent the situation in joint tissues.

As shown in an in vitro study, the expression of NUCB2 mRNA and NUCB2/nesfatin-1 protein was detected in human primary chondrocytes and murine ATD-5 chondrocytes (46). The cytoplasmic location of nesfatin-1 in these cells was also demonstrated. Furthermore, mRNA and protein expression was increased during maturation of chondrocytes, which suggests that nesfatin-1 may play a role in chondrocyte differentiation and cartilage maturation. It might also be a marker of late-phase chondrogenic differentiation and might affect endochondral ossification. The increase observed in its expression during the maturation of chondrocytes confirms previous assumptions by Petersson et al. (42). Nesfatin-1 can also induce chemotactic and pro-inflammatory mediators, such as interleukin-8 (IL-8), interleukin-6 (IL-6), cyclooxygenase-2 (COX-2), and macrophage inflammatory protein-1 alfa (MIP-1 alfa), in human primary chondrocytes (46). It also induces IL-6, MIP-1 alfa, and COX-2 in murine differentiated chondrocytes in combination with IL-1 (46). On the other hand, IL-1 and TNF-alfa (tumor necrosis factor-1) increase NUCB2 mRNA expression as well as NUCB2/nesfatin-1 synthesis in human primary chondrocytes and murine differentiated chondrocytes. As indicated by the research, pro-inflammatory cytokines in chondrocytes are also induced by other adipokines. Conde et al. $(9,10)$ and Gomez et al. $(25)$ have shown that leptin and adiponectin participate in inflammation and immune response in whole joint tissues and in rheumatic diseases, such as osteoarthritis and/or rheumatoid arthritis. Thus, these findings suggest that nesfatin-1 may participate, together with other adipokines, in the pathogenesis and/or progression of inflammatory complications of cartilage degenerative diseases. Moreover, it seems that nesfatin-1 may play a protective role or respond to osteoarthritis.

Research concerning the role of nesfatin-1 in bone metabolism and properties has been very limited. $\mathrm{Li}$ et al. (32) found the expression of NUCB2/nesfatin-1 mRNA in osteoblast and osteoclast cell lines in an in vitro study. It was also demonstrated that NUCB2/ nesfatin-1 significantly increased the activity of alkaline phosphatase (ALP), a representative marker of osteoblastic differentiation, in pre-osteoblastic cells in a dose-dependent manner. However, this effect was found to be dependent on recombinant human bone morphogenetic protein-2 (rhBMP2), since NUCB2/ nesfatin-1 itself had no direct effect on the ALP activity. In contrast, NUCB2/nesfatin-1 improved mineralization with no addition of rhBMP2. Moreover, NUCB2/ nesfatin-1 reduced osteoclastogenesis by inhibiting macrophage differentiation towards osteoclasts (32). The influence of nesfatin- 1 on bone cells is similar to the effect of other adipokines, e.g. visfatin stimulates osteoblast proliferation and inhibits osteoclastogen- esis, whereas resistin stimulates both osteoblast proliferation and osteoclast differentiation $(36,52,59)$. Adiponectin alters bone metabolism, promoting bone formation and inhibiting bone resorption $(33,40,60)$. It also influences chondrocyte proliferation, matrix synthesis, and mineralization (8). The leptin effect on bone metabolism is not fully clear. As demonstrated in the same studies, leptin has a protective effect on bone formation and bone mineral content $(4,5)$; on the other hand, it inhibits bone formation through the nervous system (13).

In an in vivo study, intravenous administration of NUCB2/nesfatin-1 was found to increase bone mineral density of femora and lumbar vertebrae in ovariectomized rats, which are a classic animal model for postmenopausal osteoporosis (32). In another study conducted in female rats undergoing ovariectomy, exogenous nesfatin- 1 protected the growth cartilage of long bones. The thickness of the growth plate in ovariectomized rats after nesfatin-1 treatment was similar to that in control animals (53).

As mentioned earlier, nesfatin-1 can induce proinflammatory cytokines, and the nesfatin- 1 serum level is elevated in osteoarthritis incidences. Elevated serum nesfatin-1 levels were also connected with osteopenic changes observed after gastric resection (43). Pro-inflammatory cytokines, in addition to arthritis and cartilage disorders, are also involved in bone remodeling and pathogenesis of osteoporosis. They are key regulators of osteoclastogenic activity and stimulate bone resorption, leading to bone loss and negative changes in its structure and properties. Given the above, it can be supposed that the increase in nesfatin-1 in blood may be a protective mechanism against changes in osteopenic bone. A confirmation of this thesis may be the protective effect of nesfatin- 1 on bone tissue in ovariectomized rats $(32,53)$.

In summary, it seems that nesfatin-1 may play a protective role in cartilage and bone diseases, but the mechanism of its action is ambiguous. Therefore, further studies are required to investigate the exact role of nesfatin-1 and to determine whether this adipokine can be used for monitoring and treatment of cartilage and bone diseases.

\section{References}

1. Anwar G. M., Yamamah G., Ibrahim A., El-Lebedy D., Farid T. M., Mahmoud R. Nesfatin-1 in childhood and adolescent obesity and its association with food intake, body composition and insulin resistance. Regul. Pept. 2014, 188, 21-24.

2. Atsuchi K., Asakawa A., Ushikai M., Ataka K., Tsai M., Koyama K., Sato Y., Kato I., Fujimiya M., Inui A.: Centrally administered nesfatin-1 inhibits feeding behaviour and gastroduodenal motility in mice. Neuroreport. 2010, 21, 1008-1011.

3. Barnikol-Watanabe S., Gross N. A., Gotz H., Henkel T., Karabinos A., Kratzin H., Barnikol H. U., Hilschmann N.: Human protein NEFA, a novel DNA binding/ EF-hand/leucine zipper protein. Molecular cloning and sequence analysis of the cDNA, isolation and characterization of the protein. Biol. Chem. Hoppe Seyler 1994, 375, 497-512.

4. Bartell S. M., Rayalam S., Ambati S., Gaddam D. R., Hartzell D. L., Hamrick M., She J. X., Della-Fera M. A., Baile C. A.: Central (ICV) leptin injection increases bone formation, bone mineral density, muscle mass, serum IGF-1, and the 
expression of osteogenic genes in leptin-deficient ob/ob mice. J. Bone Miner. Res. 2011, 26, 1710-1720.

5. Bertoni L., Ferretti M., Cavani F., Zavatti M., Resca E., Benelli A., Palumbo C.: Leptin increases growth of primary ossification centers in fetal mice. J. Anat. 2009, 215, 577-583.

6. Brailoiu G. C., Dun S. L., Brailoiu E., Inan S., Yang J., Chang J. K., Dun N. J.: Nesfatin-1: distribution and interaction with G-protein-coupled receptor in the rat brain. Endocrinol. 2007, 148, 5088-5094.

7. Buttler A. A.: More news about NUCB2/nesfatin-1: A new factor in the hypothalamic control of glucose homeostasis? Diabetes 2012, 61, 1920-1922.

8. Challa T. D., Rais Y., Ornan E. M.: Effect of adiponectin on ATDC5 proliferation, differentiation and signaling pathways. Mol. Cell. Endocrinol. 2010, 323, 282-291.

9. Conde J., Gómez R., Bianco G., Scotece M., Lear P., Dieguez C., Gómez-Reino J., Lago F., Gualillo $O$.: Expanding the adipokine network in cartilage: identification and regulation of novel factors in human and murine chondrocytes. Ann. Rheum. Dis. 2011, 70, 551-559.

10. Conde J., Scotece M., Lopez V., Gómez R., Lago F., Pino J., Gómez-Reino J. J., Gualillo $O$.: Adiponectin and leptin induce VCAM-1 expression in human and murine chondrocytes. PLoS ONE 2012, 7 (12):e52533.

11. Diggs-Andrews K. A., Zhang X., Song Z., Daphna-Iken D., Routh V. H., Fisher S. J.: Brain insulin action regulates hypothalamic glucose sensing and the counter regulatory response to hypoglycemia. Diabetes 2010, 59, 2271-2280.

12. Douglas A. J., Johnstone L. E., Leng G.: Neuroendocrine mechanism of change in food intake during pregnancy: a potential role for brain oxytocin. Physiol. Behav. 2007, 91, 352-365.

13. Ducy P., Amling M., Takeda S., Priemel M., Schilling A. F., Beil F. T., Shen J., Vinson C., Rueger J. M., Karsenty G.: Leptin inhibits bone formation through a hypothalamic relay: a central control of bone mass. Cell 2000, 100, 197-207.

14. Foo K., Brismar H., Broberger C.: Distribution and neuropeptide coexistence of nucleobindin-2 $\mathrm{mRNA} /$ nesfatin-like immunoreactivity in the rat CNS. Neurosci. 2008, 156, 563-579.

15. Foo K., Brauner H., Ostenson C. G., Broberger C.: Nucleobindin-2/nesfatin in the endocrine pancreas: distribution and relationship to glycaemic state. J. Endocrinol. 2010, 204, 255-263.

16. Fort P., Salvert D., Hanriot L., Jego S., Shimizu H., Hashimoto K., Mori M., Luppi $P$. H.: The satiety molecule nesfatin-1 is co-expressed with melanin concentrating hormone in tuberal hypothalmic neurons of the rat. Neurosci. 2008, $155,174-178$.

17. Garcia-Galiano D., Navarro V. M., Gaytan F., Tena-Sempere M.: Expanding roles of NUCB2/nesfatin-1 in neuroendocrine regulation. J. Mol. Endocrinol 2010, 45, 281-290.

18. Garcia-Galiano D., Navarro V.M., Roa J., Ruiz-Pino F., Sanchez-Garrido M. A., Pineda R., Castellano J. M., Romero M., Aguilar E., Gaytán F., Diéguez C., Pinilla L., Tena-Sempere M.: The anorexigenic neuropeptide, nesfatin-1, is indispensable for normal puberty onset in the female rat. J. Neurosci. 2010, 30, 7783-7792.

19. Garcia-Galiano D., Pineda R., Ilhan T., Castellano J. M., Ruiz-Pino F., Sanchez-Garrido M. A., Vazquez M. J., Sangiao-Alvarellos S., Romero-Ruiz A., Pinilla L., Diéguez C., Gaytán F., Tena-Sempere M.: Cellular distribution, regulated expression, and functional role of the anorexigenic peptide, NUCB2/ nesfatin-1, in the testis. Endocrinol. 2012, 153, 1959-1971.

20. Goebel M., Stengel A., Wang L., Lambrecht N. W., Taché Y.: Nesfatin-1 immunoreactivity in rat brain and spinal cord autonomic nuclei. Neurosci. Lett. 2009 452, 241-246.

21. Goebel M., Stengel A., Wang L., Taché Y.: Central nesfatin-1 reduces the nocturnal food intake in mice by reducing meal size and increasing inter-meal intervals. Peptides 2011, 32, 36-43.

22. Goebel M., Stengel A., Wang L., Taché Y.: Restraint stress activates nesfatin-1-immunoreactive brain nuclei in rats. Brain Res. 2009, 1300, 114-124

23. Goebel-Stengel M., Wang L.: Central and peripheral expression and distribution of NUCB2/nesfatin-1. Curr. Pharm. Des. 2013, 19, 6935-6940.

24. Goebel-Stengel M., Wang L., Stengel A., Taché Y.: Localization of nesfatin-1 neurons in the mouse brain and functional implication. Brain Res. 2011, 1396, 20-34.

25. Gómez R., Scotece M., Conde J., Gómez-Reino J. J., Lago F., Gualillo O.: Adiponectin and leptin increase IL-8 production in human chondrocytes. Ann. Rheum. Dis. 2011, 70, 2052-2054.

26. Gonzalez R., Reingold B. K., Gao X., Gaidhu M. P., Tsushima R. G., Unniappan S. Nesfatin-1 exerts a direct, glucose-dependent insulinotropic action on mouse islet beta- and MIN6 cells. J. Endocrinol. 2011, 208, R9-16.

27. Gonzalez R., Tiwari A., Unniappan S.: Pancreatic beta cells colocalize insulin and pronesfatin immunoreactivity in rodents. Biochem. Biophys. Res. Commun. 2009, 381, 643-648.

28. Iida T., Domoto T., Takigawa A., Nakamura S., Kato Y., Togo M., Chikamura C., Harada T., Ishizaki F., Ono Y.: Relationships among blood leptin and adiponectin levels, fat mass, and bone mineral density in Japanese pre- and postmenopausal women. Hiroshima J. Med. 2011, 60, 71-78.

29. Inoue H., Hiraoka K., Hoshino T., Okamoto M., Iwanaga T., Zenmyo M., Shoda T., Aizawa H., Nagata K.: High levels of serum IL-18 promote cartilage loss through suppression of aggrecan synthesis. Bone 2008, 42, 1102-1110.

30. Jiang L., Bao J., Zhou X., Xiong Y., Wu L.: Increased serum levels and chondrocyte expression of nesfatin- 1 in patients with osteoarthritis and its relation with BMI, hsCRP, and IL-18. Mediators Inflamm. 2013, 2013:631251, doi: $10.1155 / 2013 / 631251$.

31. Kohno D., Nakata M., Maejima Y., Shimizu H., Sedbazar U., Yoshida N., Dezaki K., Onaka T., Mori M., Yada T.: Nesfatin-1 neurons in paraventricular and supraoptic nuclei of the hypothalamus coexpress oxytocin and vasopressin and are activated by refeeding. Endocrinol. 2008, 149, 1295-1301.

32. Li R., Wu Q., Zhao Y., Jin W., Yuan X., Wu X., Tang Y., Zhang J., Tan X., Bi F., Liu J. N.: The novel pro-osteogenic activity of NUCB21-83. PLoS ONE 2013, 8 (4): e61619.

33. Luo E., Hu J., Bao C., Li Y., Tu Q., Murray D., Chen J.: Sustained release of adiponectin improves osteogenesis around hydroxyapatite implants by suppressing osteoclast activity in ovariectomized rabbits. Acta Biomat. 2012, 8, 734-743.

34. Maejima Y., Sedbazar U., Suyama S., Kohno D., Onaka T., Takano E., Yoshida N., Koike M., Uchiyama Y., Fujiwara K., Yashiro T., Horvath T. L., Dietrich M. O., Tanaka S., Dezaki K., Oh I. S., Hashimoto K., Shimizu H., Nakata M., Mori M., Yada T.: Nesfatin-1-regulated oxytocinergic signaling in the paraventricular nucleus causes anorexia through a leptin-independent melanocortin pathway. Cell Metab. 2009, 10, 355-365.

35. Miura K., Kurosawa Y., Kanai Y.: Calcium-binding activity of nucleobindin mediated by an EF hand moiety. Biochem. Biophys. Res. Commun. 1994, 199, 1388-1393.

36. Moschen A. R., Geiger S., Gerner R., Tilg H.: Pre-B cell colony enhancing factor/ NAMPT/visfatin and its role in inflammation-related bone disease. Mutat. Res. 2010, 690, 95-101.

37. Nakata M., Manaka K., Yamamoto S., Mori M., Yada T.: Nesfatin-1 enhances glucose-induced insulin secretion by promoting $\mathrm{Ca}(2+)$ influx through L-type channels in mouse islet beta-cells. Endocr. J. 2011, 58, 305-313.

38. Oh-I S., Shimizu H., Satoh T., Okada S., Adachi S., Inoue K., Eguch H., Yamamoto M., Imaki T., Hashimoto K., Tsuchiya T., Monden T., Horiguchi K., Yamada M., Mori M.: Identification of nesfatin-1 as a satiety molecule in the hypothalamus. Nature 2006, 443, 709-712.

39. Okere B., Xu L., Roubos E. W., Sonetti D., Kozicz T.: Restraint stress alters the secretory activity of neurons co-expressing urocortin-1, cocaine- and amphetamine-regulated transcript peptide and nesfatin- 1 in the mouse Edinger-Wstphal nucleus. Brain Res. 2010, 1317, 92-99.

40. Oshima K., Nampei A., Matsuda M., Iwaki M., Fukuhara A., Hashimoto J., Yoshikawa H., Shimomura I.: Adiponectin increases bone mass by suppressing osteoclast and activating osteoblast. Bioch. Bioph. Res. Commun. 2005, 331, 520-526.

41. Pearle A. D., Scanzello C. R., George S., Mandl L. A., DiCarlo E. F., Peterson M., Sculco T. P., Crow M. K.: Elevated high sensitivity C-reactive protein levels are associated with local inflammatory findings in patients with osteoarthritis. Osteoarth. Cartil. 2007, 15, 516-523.

42. Petersson U., Somogyi E., Reinholt F. P., Karlsson T., Sugars R. V., Wendel M.: Nucleobindin is produced by bone cells and secreted into the osteoid, with a potential role as a modulator of matrix maturation. Bone 2004, 34, 949-960.

43. Puzio I., Kapica M., Bieńko M., Radzki R., Pawłowska M., Tymcki G.: Fundectomy, antrectomy and gastrectomy influence densitometric, tomographic and mechanical bone properties as well as serum ghrelin and nesfatin-1 levels in rats. Med. Weter. 2014, 70, 604-609.

44. Ramanjaneya M., Chen J., Brown J., Tripathi G., Hallschmid M., Patel S., Kern W., Hillhouse E. W., Lehnert H., Tan B. K., Randeva H. S.: Identification of nesfatin-1 in human and murine adipose tissue: a novel depot-specific adipokine with increased levels in obesity. Endocrinol. 2010, 151, 3169-3180.

45. Rhie Y. J., Lee K. H., Chung S. C., Kim H. S., Kim D. H.: Effects of body composition, leptin, and adiponectin on bone mineral density in prepubertal girls. J. Korean Med. Sci. 2010, 25, 1187-1190.

46. Scotece M., Conde J., Abella V., Lopez V., Lago F., Pino J., Gomez-Reino J. J., Gualillo $O .:$ NUCB2/nesfatin-1: a new adipokine expressed in human and murine chondrocytes with pro-inflammatory properties, an in vitro study. J. Orthop. Res. 2014, 32, 653-660.

47. Shimizu H., Oh-I S., Hashimoto K., Nakata M., Yamamoto S., Yoshida N., Eguchi H., Kato I., Inoue K., Satoh T., Okada S., Yamada M., Yada T., Mori M.: Peripheral administration of nesfatin-1 reduces food intake in mice: The leptin-independent mechanism. Endorcinol. 2009, 150, 662-671.

48. Stengel A., Goebel M., Yakubov I., Wang L., Witcher D., Coskun T., Tache Y., Sachs G., Lambrecht N. W.: Identification and characterization of nesfatin-1 immunoreactivity in endocrine cell types of the rat gastric oxyntic mucosa. Endocrinol. 2009, 150, 232-238. 
49. Stengel A., Tache Y: Nesfatin-1 role as possible new potent regulator of food intake. Regul. Pept. 2010, 163, 18-23.

50. Stengel A., Tache Y.: Role of brain NUCB2/nesfatin-1 in the regulation of food intake. Curr. Pharm. Des. 2013, 19, 6955-6959.

51. Su Y., Zhang J., Tang Y., Bi F., Liu J. N.: The novel function of nesfatin-1: anti-hyperglycemia. Biochem. Biophys. Res. Commun. 2010, 391, 1039-1042.

52. Thommesen L., Stunes A. K., Monjo M., Grosvik K., Tamburstuen M. V., Kjobli E. Lyngstadaas S. P., Reseland J. E., Syversen U.: Expression and regulation of resistin in osteoblasts and osteoclasts indicate a role in bone metabolism. J. Cell. Biochem. 2006, 99, 824-834.

53. Tymicki G., Pawłowska M., Puzio I.: Ocena wpływu nesfatyny-1 na chrząstkę wzrostową kości udowych samic szczurów. III Forum Młodych Przyrodników, Rolnictwo, Zdrowie, Żywność. Lublin, 21.05.2016. Książka streszczeń, s. 26-27.

54. Vas S., Adori C., Konczol K., Katai Z., Pap D., Papp R. S., Bagdy G., Palkovits M., Toth Z. E.: Nesfatin-1/NUCB2 as a potential new element of sleep regulation in rats. PLoS ONE 2013, 8:e59809.

55. Watanabe A., Mochiki E., Kimura A., Kogure N., Yanai M., Ogawa A., Toyomasu Y. Ogata K., Ohno T., Suzuki H., Kuwano H.: Nesfatin-1 suppresses gastric contractions and inhibits interdigestive migrating contractions in conscious dogs. Dig. Dis. Sci. 2015, 60, 1595-1602.

56. Wernecke K., Lamprecht I., Johren O., Lehnert H., Schulz C.: Nesfatin-1 increases energy expenditure and reduces food intake in rats. Obesity (Silver Spring) 2014, $22,1662-1668$

57. Wu N., Wang Q. P., Li H., Wu X. P., Sun Z. Q., Luo X. H.: Relationships between serum adiponectin, leptin concentrations and bone mineral density, and bone biochemical markers in Chinese women. Clin. Chim. Acta 2010, 411, 9-10.

58. Xia Z. F., Fritze D. M., Li J. Y., Chai B., Zhang C., Zhang W., Mulholland M. W. Nesfatin-1 inhibits gastric acid secretion via a central vagal mechanism in rats. Am. J. Physiol. Gastrointest. Liver Physiol. 2012, 303, G570-577.

59. Xie H., Tang S. Y., Luo X. H., Huang J., Cui R. R., Yuan L. Q., Zhou H. D., Wu X. P., Liao E. Y.: Insulin-like effects of visfatin on human osteoblasts. Calcif. Tissue Int. 2007, 80, 201-210.
60. Yamaguchi N., Kukita T., Li Y. J., Martinez Argueta J. G., Saito T., Hanazawa S., Yamashita Y.: Adiponectin inhibits osteoclast formation stimulated by lipopolysaccharide from Actinobacillus actinomycetemcomitans. FEMS Immun. Med. Microb. 2007, 49, 28-34.

61. Yamawaki H., Takahashi M., Mukohda M., Morita T., Okada M., Hara Y.: Anove adipocytokine, nesfatin-1 modulates peripheral arterial contractility and blood pressure in rats. Biochem. Biophys. Res. Commun. 2012, 418, 676-681.

62. Yoshida N., Maejima Y., Sedbazar U., Ando A., Kurita H., Damdindorj B. Takano E., Gantulga D., Iwasaki Y., Kurashina T., Onaka T., Dezaki K., Nakata M., Mori M., Yada T.: Stressor-responsive central nesfatin-1 activates corticotropin-releasing hormone, noradrenaline and serotonin neurons and evokes hypothalamic-pituitary-adrenal axis. Aging (Albany NY) 2010, 2, 775-784.

63. Yosten G. L., Samson W. K.: Nesfatin-1 exerts cardiovascular actions in brain: possible interaction with the central melanocortin system. Am. J. Physiol. Regul. Integr. Comp. Physiol. 2009, 297, R330-R336.

64. Yosten G. L., Redlinger L., Samson W. K.: Evidence for a role of endogenous nesfatin-1 in the control of water drinking. J. Neuroendocrinol. 2012, 24, 1078-1084 .

65. Zhang A. Q., Li X. L., Jiang C. Y., Lin L., Shi R. H., Chen J. D., Oomura Y. Expression of nesfatin-1/NUCB2 in rodent digestive system. World J. Gastroenterol. 2010, 16, 1735-1741.

66. Zhang H., Xie H., Zhao Q., Xie G.-Q., Wu X.-P., Liao E.-Y., Luo X.-H. Relationships between serum adiponectin, apelin, leptin, resistin, visfatin levels and bone mineral density, and bone biochemical markers in postmenopausal Chinese women. J. Endocrinol. Invest. 2010, 33, 707-711.

67. Zhang Y., Shui X., Lian X., Wang G.: Serum and Synovial Fluid Nesfatin-1 Concentration is Associated with Radiographic Severity of Knee Osteoarthritis. Med. Sci. Monit. 2015, 21, 1078-1082.

Corresponding author: Iwona Puzio, DVM, PhD Hab., Akademicka 12, 20-033 Lublin, Poland; e-mail: iwona.puzio@up.lublin.pl 